\title{
Inner Strength of Female Characters in Loitering with Intent and The Public Image by Muriel Spark
}

\section{ABSTRACT}

Women characters in Muriel Spark's novels are diverse, some strong and powerful, some weak and unable to make decisions. And there are characters who develop throughout the novel and learn from their own mistakes. From being passive, they gradually start acting and making their own choices. Loitering with Intent and The Public Image present women characters who go through metamorphosis, from being dependent on others into living their own lives and freeing themselves from former influences. Such kaleidoscopic change enables them not only to be able to finally make their own decisions but also to overcome many difficult situations threatening their future life.

Fleur Talbot, a heroine in Loitering with Intent, finds herself at a point in which she thinks that everything she cares for is lost. Chronically passive and naïve, she cannot imagine another way of being until she understands that she is being cheated, that her life will be ruined if she does not act. Everyone around her seems to be in conspiracy against her; only taking a firm stand and opposing her surrounding world can help. Fleur's life has become totally dependent on her ability to be strong and decisive. She knows that if she remains what she is, her career and prospects for the future will be lost, so she decides to prove her determination and her will to be finally happy. Her transformation into a powerful character saves her dignity and makes her a successful writer.

Annabel, a character in The Public Image is the same type of person as Fleur, as she lacks self-confidence and has no support from anybody, even her own husband. Muriel Spark, however, presents her as another example of a heroine who develops as the action progresses, able to evoke strength in herself when her situation seems hopeless. Annabel, at first treated as a puppet in the hands of other people, who use her image for their own benefit, shows that she is capable of anything by the 
book's end. When her career and reputation are threatened and her privacy invaded, she decides to leave the country. This requires both effort and sacrifice, as she has to leave behind everything she has worked for all her life, but this is the necessary price for her freedom.

The ability of both female characters to show so much determination reveals an inherent inner strength, and their weakness and vulnerability as just superficial. When the situation requires it, both Annabel and Fleur are ready to fight for their rights, for their freedom and self esteem, and they discover that they are indeed capable of changing their lives.

\section{Abstract}

There are certain women in Muriel Spark's stories who appear weak and vulnerable, with dreams but no power to realize them, with hopes but no means to counter the obstacles to fulfilment. But this impression can change as the action progresses. These women are capable of finding an inner strength, mustering the nerve to push against the barriers that stand between themselves and their goals.

One such character is Fleur Talbot in Loitering with Intent. Valerie Shaw says, "The book is full of ambiguities which Fleur sees but refuses to find disturbing or in any sense disabling" (Shaw 64). This is perhaps the reason for her passivity and weakness. She does not perceive the problems in her life with clear vision; instead, being a writer and an artist, she tries to distance herself from the surrounding world and live in her own shell, as if afraid to make any decision or move. She is a young, educated girl; but she completely lacks confidence, this lack issuing, among other things, from the fact that she is unemployed, driven by dreams that may never be realized, and with no concrete prospects for the future.

From the very beginning of the book, Fleur is presented as having never-ending problems with her landlord, which she could end easily if only she took the right action. She rents a single room, for which she pays double, and she is constantly reminded that she should be paying even more. Instead of reacting assertively, arguing about the rent or threatening to move out, she says nothing and meekly avoids conversations with the landlord.

Fleur also has problems with her emotions and love life, and this is another factor that entwines her life in stultifying complication. When she is confronted by Dottie, a girl whose husband she sleeps from time to time with, she explains to her: 
Yes, Dottie, I love him off and on, when he doesn't interfere with my poetry and so forth. In fact, I've started a novel which requires a lot of poetic concentration, because, you see, I conceive everything poetically. So perhaps it will be more off than on with Leslie. (Spark, Loitering 21)

She seems bereft of any deeper feelings, even dissociated, impelling Dottie to say that she has an "unnatural attitude" and that her "head rules her heart" (Spark, Loitering 21). Nevertheless, when Leslie calls her his mistress, she denies it, saying she is his girlfriend, which suggests that she is not blithely ignorant about this situation but that she simply refuses to take responsibility for a more serious relationship. Fleur also claims Dottie is her friend, perhaps fearful of having no one to talk to, or, worse, having an outright foe. However, this kind of friendship, just like her relationship with the married man, is unhealthy and causes many problems. Dottie is not really the person to wish Fleur well. She is envious of her, and more often hates than likes her, a situation Fleur's apparent passivity is incapable of changing.

After being unemployed for some time, Fleur starts a new job with the Autobiographical Association, a group of writers wanting to publish their autobiographies in seventy years' time, after their death. Sir Quentin, the Association's leader, willingly employs Fleur, who seems to be just the kind of person the organization needs. She speaks little, is hard-working and works for next to nothing. It is now that she starts writing her first novel Warrender Chase. From the very beginning, the manuscript evokes strong feelings in the people to whom she reads it. They either like it or hate it; there is nothing in between. Dottie, when Fleur first reads it to her, is confused about the plot, does not know whose side she is supposed to be on, and therefore does not like it at all. The fact that Fleur has had the courage to read the novel for the first time to Dottie and is then criticized evokes such strong feelings that she "... tore up the pages of the novel and stuffed them into the wastepaper basket, burst out crying and threw her [Dottie] out roughly and noisily" (Spark, Loitering 53). The reader may thus suspect that the book will be a success when published, because only memorable works become bestsellers. Fleur's true friends, on the other hand, have a very positive attitude towards the book. Lady Edwina, her employer's elderly, eccentric mother and Solly, her old friend, are the only people who seem to understand the girl and acknowledge her real talent.

Fleur, no matter how much she is complimented on her writing skills and her talent, denies her own potential and believes in her failure. Lady Edwina, who believes Fleur will become a famous author, remarks while visiting Fleur's home that her room is similar to those of other successful writers before they became famous. Fleur objects: 
Now I hastened to assure her that this wasn't likely. It rather frightened me to think of myself in a successful light, it detracted in my mind from the quality of my already voluminous writings from amongst which eight poems only had been published in little reviews. (Spark, Loitering 37)

At the same time, while editing the biographies of the members of the Association, and adding to them certain details, Fleur and the members themselves recognize that the works are much more readable, if not exactly interesting. When Sir Quentin realizes that the improved versions are better than the originals, he tells her to change all the works. Again, instead of talking to him about the problem, mindful that it takes time and effort to rewrite others' biographies, she keeps silent and does the job. Joseph Hynes states that "Fleur's intention has been harmless-that of an editor or of an author in search of some telling details" (174). But what she later finds is that "Sir Quentin subsequently builds on her versions with an eye to creating eventually 'lives' for his members that will enable him to blackmail them" (Hynes 174-75). This is the point when her indifference vanishes. She tries desperately to think of a way out of this situation, but it appears intractable. She says:

As you know I had already suspected that Sir Quentin was engaged in some form of racket, with maybe an eye to blackmail. At the same time I didn't see where the blackmail came in. He was not losing money on the project; on the other hand he was apparently quite rich and the potential victims of the Association were more marked in character by their once-elevated social position than for the outstanding wealth which tempts the crude blackmailer. Some of them had actually fallen on hard times. I noticed by the correspondence that the four members who had not shown up at the meeting were already trying to wriggle out of it, and I too had decided that as soon as my vague uneasiness and my suspicions about Sir Quentin's motives should crystallize into anything concrete I would simply leave. (Spark, Loitering 44-45)

Unable to act before, Fleur now finds an aim, namely, to stay in the Association and keep an eye on what is happening. Moreover, knowing that Sir Quentin is up to something nefarious, she decides to stay not only out of curiosity, to see what will happen next, but to protect herself and other members from this calculating man. Thus, in her determination to foil Sir Quentin, Fleur discovers her own innate strength.

The first thing that she uncovers is that members of the Association are given drugs to make their writings "frank." She soon works out that Sir Quentin's real interest is blackmail, something that she had once considered before. And she discovers that Sir Quentin has been reading the 
manuscript of her book secretly, stealing parts of it and adding them to the members' works. Fleur says:

I turned over one file after another, that, although nothing had been added in the form of memoirs, sheets of notes, some typed, some in Sir Quentin's hand had been inserted, familiar passages; they were lifted more or less directly from my Warrender Chase. (104)

This stimulates her anger and a desire to put an end to Sir Quentin's game. Velma Burgeois Richmond observes that "initially evil appears to be too incredible to seem real, but then its truth is recognized. Fleur first suspects, and then knows, that Sir Quentin is a lunatic. She confronts him and insists that the manipulation stop" (Richmond 158). Unfortunately, she is ranged against too many people, and it seems that her attempt to save members from abuse and blackmail will be thwarted. And the goal of getting her book published appears just as great a struggle.

But from the moment Fleur finishes her novel, everything changes. She now treats it as a mother treats her own child. The readers can finally see Fleur as a warrior, a woman of power, who will fight for her rights, even if the situation seems hopeless. Fleur's will has consolidated, and so has her determination to reveal the truth, though this now appears nearly impossible to achieve, as Sir Quentin has decided to steal the manuscript, incorporate most of it in the autobiographies of the members, and publish them as their own work. But she will not countenance defeat. She uses all available means to obtain what she wants and cares for, ultimately paying back her trespassers in kind, turning against them their own methods of deceit, trickery and manipulation.

At this point of the book, one may easily agree with Valerie Shaw that Fleur " . . . is every bit as much of a manipulator, and as secretive, as Sir Quentin..." (Shaw 65), because she appears to be a very different person now than at the book's start, acting robustly to save her manuscript and uncover the truth. Aided by her only real friend, Lady Edwina, her loneliness fades away, and she hatches a perfect plan to get back what is rightfully hers. Fleur achieves her goals: finding her manuscript, revealing that it was Sir Quentin, not she, who plagiarized the manuscript, and proving that the novel Warrender Chase is her own work, not the members'.

From a silent, confused girl, timidly disbelieving her own potential, Fleur burgeons into a powerful woman, a published writer, who is at last not afraid to confront her landlord, nor to refuse to have a dinner with his family. The new order she has established in her own life echoes the ending in Warrender Chase. Now, endowed with the almost God-like qualities of predicting the future in her book, she can "go on her way rejoicing" (Spark, Loitering 158). 
The Public Image finishes in the same way. Annabel, a beautiful actress, can be free and happy only after she has put her own strength to the test and fought for her rights. Unfortunately, and echoing Fleur's case, she needs the right stimulus to discover the potential in herself, to abandon the image of herself both as a helpless wife trying to satisfy her husband Frederick and as an inept, docile actress. Adam Sumera writes that in The Public Image, "Muriel Spark presents a world full of immorality, a world in which lies and manipulation are the usual thing" (64). In this world, survival depends on either redoubtable inner strength or a measure of that world's own dishonesty and corruption. Small wonder, then, that Annabel—naïve and unwordly_cannot find her way. Judy Sproxton notices that:

Annabel Christopher is ostensibly the victim of the film world in which she works; but a close reading of this book shows that the forces which undermine her are jealousy and deceipt. Her own ignorance of the existence of these forces makes her vulnerable to them (130-31).

She clearly cannot accept the fact that her husband, whom she trusts, could ever deceive her or be envious of her career. She seems to have put her husband's enjoyment first all her life. He ridicules her in front of his friends, calling her stupid and "insignificant" (Spark, The Public Image 11), and she merely accepts it with a smile. Frederick, also an actor, has a sense of superiority over his wife and cannot stand her shallowness:

She did not need to be clever, she only had to exist; she did not need to perform, she only had to be there in front of the cameras. She said so to Frederick, as if amazed that she had not thought of it before. He was exasperated, seeing shallowness everywhere. (Spark, The Public Image 11)

What Frederick truly cannot stand is his wife's success. She starts to earn much more than him, and real fame beckons, even though, in his opinion, she has not earned it. He says, "You can't act. You're just lucky to get parts" (11), with which Annabel agrees. So at the heart of this marriage is a husband's burning indignation that he has been unfairly-worse, unwillingly_-bested by his wife. And her submission to him creates in his mind only a sharper picture of life's injustice. Even more painful, though, becomes the thought that his wife may not be as stupid as he imagined. In fact, she copes well with the publicity, with discussion of contracts and answering to mail. Undeniably, "her new professional life had indeed sharpened her wits" (Spark, The Public Image 13). Unconsciously, Frederick might be aware that his wife's weakness and helplessness are just figments 
of his imagination, or more, his desire. Riven with complexes, he tries to maintain his belief in his superiority and her lack of talent and education. But when reality encroaches deeper into this belief, he feels threatened, his ego begins to splinter, and he seeks new ways to assert himself. To prove his masculinity, he starts seeing other women. He is attracted to very young girls and young actresses, sleeps with them, and repeatedly considers leaving Annabel for one of them. But as her career flourishes and his declines, he chooses to stay close to her money. So dispirited that he does not even try for auditions, Frederick increasingly fetches up at home, where he spends much of his time doing nothing. Ironically, Annabel creates a new kind of role for him when they start to promote themselves as the perfect couple. Now he too is photographed and interviewed. But behind this is the acidic knowledge that this is happening only because of his wife's success. Frederick, behaving like a spoilt child, can envision happiness only in triumph over Annabel in all walks of life, and he is to be disappointed.

The only place the marriage is truly ideal is on the covers of glossy magazines. Peter Kemp says that "the marriage central to the book is an appalling travesty, a union held together by hate rather than love" (118). Frederick stops sleeping at home, appearing there only from time to time, and Annabel realizes that his friend Billy now knows more about him than she does. The situation worsens. Annabel wants to keep her public image perfect and Frederick cares only for his wife's money. Annabel, passive since the beginning of the book, again holds that their marriage might not be a perfect one but that everything will be all right in the end, that the current malaise is temporary. She also seems somewhat hypocritical, caring more about their image than reality as a couple. She is capable of viewing their relationship with cool disinterest, creating in her mind a picture of what it should look like, then comparing this perfection with the awkward reality. In fact, this is the problem that disturbs her most, not the fact that they do not love each other anymore. She cannot be blamed for the lack of feeling in her life, but rather for having no reasons to stay with Frederick yet doing so, and this leads to a catastrophe.

The novel's climax comes when Frederick gives a party at their flat, without informing Annabel. He does not even come to it himself, just tells the guests that he will arrive soon. When she hears knocking on the door, Annabel, alone with her baby, opens it and is nonplussed. To refuse entry to the guests would be rude, especially if they have been invited by her husband, so, mindful of her public image, she lets them in. "It was impossible to explain, afterwards, why she had not sent them all packing. She was not sure, herself, how it was that the whole event happened beyond her control" (Spark, The Public Image 47). What happens after the 
party will be Annabel's biggest challenge. At the very time that Frederick's invited guests are milling around the flat, Frederick himself commits suicide. And in retribution against his overly-successful wife, he leaves notes to his friends and family, goodbye letters in which he accuses her of, among other things, infidelity, neglect, drinking, drug abuse and attending orgies. Anna Walczuk states that:

Frederick's suicide, apparently caused by his feelings of resentment, malice and a sense of estrangement, gets transformed into the death of a martyr who, with an unshaken fidelity and loyalty to his wife, resists the advances of women enamoured with him, and eventually dies falling off the scaffolding while being chased by them (256-57).

Now Annabel has to act herself; there is nobody to rely on. Her husband's friend Billy, sure she cannot cope by herself, explains to her director, "You must remember she's only a woman. She isn't as tough as you think" (Spark, The Public Image 118). Then, taking copies of the letters, he blackmails her. Adam Sumera justifiably calls this character "a parasite" and adds that "he sponges on them in the usual way of a scrounger until he finally shows his true face in blackmailing Annabel" (65). This is a moment when Annabel has to accept reality, whether she likes it or not, and the terrible situation in which she finds herself is inextricably linked to her idealised image. She realizes that she has been deceived by both Frederick and Billy, and that there is nobody she can trust for help out of this world of lies and blackmail. Though there is nonetheless a positive-if dark—side to this debacle: "at the moment of his death, Frederick loses control over the scenario he invented for the exploitation by mass media; while Annabel, alive, can further manipulate it ..." (Walczuk 257).

Now on her own, Annabel tries to control the situation, and at first things go well. She discovers that she can defend herself and find a way to keep her good name. But the letters and Billy's blackmail are too much for her. Her lawyer advises her to pay Billy off to prevent the letters' release to the press.

Jennifer Lynn Randisi claims that, by the end of her novel, Muriel Spark, "transforms the dead object Annabel had become into a woman capable of creating a new life for herself" (65). Annabel finally proves able to pluck up courage and stand up for her rights, which are freedom and peace of mind. Norman Page says that:

Annabel takes up the challenge and for the first time acts like a free individual: in a final reversal she breaks through the web of pretence 
and deceit and leaves the country with the baby that has all along been her only link with genuine human feeling, 'the only reality of her life.' (66-67)

She shows the letters herself in court, no longer afraid of spoiling her public image, then packs her possessions and goes to Greece. For her, this is an act of great courage, not some easy escape. She could have paid the money and lived in fear; instead, she chose freedom and a normal life in a better world, properly apprehending her own strength and independence for the first time in her life.

Loitering with Intent and The Public Image seem to be completely different, the former resembling a crime story, in which a heroine tracks down a malefactor and solves a riddle, the latter presenting the struggle between the values of an inner self and a public image. But what binds them together is the image of a lost girl surrounded by a world that can suffocate her dreams and her free will. In both books a seemingly passive woman becomes a heroine, a person ready to sacrifice everything to fight for the ideas she has discovered and shaped while life threatens to nullify her. In Fleur's case, the passion for change springs from her passion for her book, which is like a newborn baby to her, and from her knowledge of the injustice Sir Quentin intends visiting on herself and others. Annabel, on the other hand, has a flesh-and-blood baby; this is her real inspiration in her fight for freedom, along with a determination to put the world of lies and duplicity behind her. They are both discoverers of a latent power, and with this power they push through an enveloping bleakness into their true selves, and happiness.

\section{Works Cited}

Hynes, Joseph. The Art of the Real. London: Associated University Press, 1988.

Kemp, Peter. Muriel Spark. London: St Ann's, 1974.

Page, Norman. Muriel Spark. London: Macmillan, 1990.

Richmond, Velma Burgeois. Muriel Spark. New York: Ungar, 1984.

Randisi, Jennifer Lynn. On Her Way Rejoicing; The Fiction of Muriel Spark. Washington: Catholic University of America Press, 1991.

Shaw, Valerie. "Fun and Games with Life-Stories", Muriel Spark: An Odd Capacity for Vision, Ed. Alan N. Bold. London: Vision, 1984.

Spark, Muriel. Loitering with Intent. England: Triad Granada, 1982.

---. The Public Image. England: Penguin, 1989. 
Sproxton, Judy. The Women of Muriel Spark. London: Constable, 1992. Stubbs, Patricia. Muriel Spark. Harlow: Longman, 1973.

Sumera, Adam. Muriel Spark's Novels. Łódź: Wydawnictwo Uniwersytetu Łódzkiego, 1996.

Walczuk, Anna. "Fiction as Muriel Spark's Comment on the Nature of Reality." Studies in English Literature and Language. Ed. Irena Przemecka and Zygmunt Mazur. Kraków: Jagiellonian University, 1995. 